\title{
THE PSYCHOLOGICAL CONSEQUENCES OF PARTICIPATION IN COMBAT MISSIONS AND THE SITUATIONAL AND SOCIAL FACTORS BEHIND THEM: AN EMPIRICAL STUDY
}

\author{
PARTICIPATION IN COMBAT MISSIONS \\ AS AN EXTREME SITUATION
}

A combat mission is the most difficult challenge a soldier can face. It requires not only comprehensive physical and tactical training, but also ideal psychological preparation. Participation in combat involves exposure to a large number of stressors. A soldier on a combat mission is constantly experiencing threats to health and life, without the support of close relatives. These circumstances make for strong stress of a chronic nature. Due to the multitude of stressors, their intensity, and their duration, combat participation in included in every classification of traumatic events (Joseph, 2007). It is considered to be a strong stressor, often exceeding the limits of psychological resistance of soldiers and leading to various psychological disturbances.

In discussing the soldiers' participation in combat missions and its consequences, it is necessary to clarify the concept of combat stress. People who have never participated in combat operations are unlikely to be able to imagine the frequent stressors this involves. The term "stress" in relation to soldiers' reactions to these experiences thus seems incomplete and not entirely accurate. For this reason, the term "battle stress" was coined: this should be understood as the normal psychological and physiological reactions of soldiers - that is, the normal reaction of soldiers to the abnormal situation of participating in a combat mission (Nowak, 2008: 5).

The aim of this article is to discuss the psychological stressors involved in combat missions and to indicate the positive and negative effects of this type of experience on soldiers' mental health. We presents the results of research aimed at verifying a hypothesis on the relation between combat experiences and the support obtained by soldiers on one hand, with both psychological disturbances (posttraumatic stress disorder) and improvements in the functioning of selected aspects of psychological life (posttraumatic growth) on the other. 


\section{CAUSES OF COMBAT STRESS}

In order to understand the stressful nature of participation in a combat mission, it is worth taking a closer look at battle situations in the context of the stressors to which soldiers are exposed. The stress factors related to the external (situational) conditions experienced by participants in combat missions include very high temperatures, acute, and prolonged noise and glaring lights (Figley, Nash, 2010: 23; Watkins, 2014; Joseph, 2007). All of these are stimuli whose strength exceeds the maximum threshold of sensitivity. In the areas of current military operations for Polish soldiers - that is, primarily in Iraq and Afghanistan - there is intense heat, which Polish citizens are not used to. For safety reasons, these soldiers must wear heavy protective clothing, including a helmet, body armor, and a weapon. This equipment is sometimes very heavy, which makes the high temperatures particularly burdensome. Military vehicles are crowded and stuffy and the windows are kept closed, due to the danger of passengers being injuring by shrapnel. The persistent noise of shelling is another stimulus that exceeds the maximum threshold of sensitivity. During patrols, soldiers are constantly accompanied by the monotonous and loud sound of working engines. Noise is an extremely intense and fatiguing stressor, because no physiological adaptation to it is possible (Figley, Nash, 2010: 25).

Long-term exposure to various types of maximum strength stimuli can lead to mental exhaustion, which results in indifference to noise, explosions, and other signs of danger. Such extreme exhaustion often results in a dulling of the self-preservation instinct (Cendrowski, Swebodzki, 1973: 27), leading soldiers to take ill-considered, risky activities that endanger their lives.

The second type of stressor includes various cognitive and informational aspects of combat missions, including: (a) soldiers' lack of information about their families and the details and purpose of the their professional duties (Figley, Nash, 2010: 27); (b) culture shock, which is the result of the immersion of a soldier in a culture completely different what he or she is used to (Lemanowicz, Szaraniec, 2003: 23); (c) prolonged deficiency of stimuli in which soldiers in certain positions (e.g., guards) are required to maintain vigilance and full readiness (Figley, Nash, 2010: 28, Watkins, 2014: 7). Particular attention should be paid to the lack of information about the purpose of the military operations in which soldiers take part. Usually, only the highest-ranking officers have access to the mission details, while lower-ranking soldiers merely carry out direct orders, which can be a source of frustration and mental discomfort. In addition, all soldiers on a mission, regardless of position in the hierarchy, struggle with insufficient information about their families (Ogley, Bradley, Santiago, Reynolds, 2012: 1282; Watkins, 2014: 4). Contact with loved ones living in the country of origin is difficult, and phone calls are usually limited. Moreover, family members typically only share "safe" information with the soldier, who might otherwise worry about problems that nothing can be done about.

Events on the mission also have a significant impact on emotion regulation. Witnessing someone's death, inflicting death, and losing friends during the mission are extreme emotional experiences (Figley, Nash, 2010: 31; Watkins, 2014: 10). Exposure to the death of other people or to their seriously injured bodies impairs the basic beliefs 
that the world is benevolent and meaningful. The experience of war challenges these beliefs, which have historically been the foundation of soldiers' worldview. Soldiers who have lost friends as a result of military activities must also face a whole range of intense feelings. Their situation, however, is extremely difficult, because the circumstances of the mission promote the suppression of emotion. Emotion expressional is here rather maladaptive, as it impedes the performance of duties. Affective state regulation thus becomes rather difficult. As a result, we observe the return of repressed emotions after returning home.

The next factor impeding emotional regulation is the feeling of helplessness. Every soldier realizes at some point that he or she has no influence on what will happen in the near future. This awareness often leads to a phenomenon called "mental degaussing" (Figley, Nash, 2010: 31), which refers to an excessive indifference to a dangerous situation. The lack of control over one's own life is thus certainly a high-strength stress stimulus.

The long list of these most important stress factors is completed by soldiers' lack of privacy and personal space (Figley, Nash, 2010: 34), which is a type of so-called social stress. Military bases are total institutions, as they engage every sphere of the life people staying there: soldiers sleep in small rooms, work together, eat meals together, and spend time together (Baranowska, 2008). Paradoxically, however, soldiers may feel lonely due to separation from and limited contact with their families. Separation from family members and the difficulty of obtaining information about their daily experiences can be a source of severe stress for soldiers on missions.

Table 1

\section{Combat stressors}

\begin{tabular}{||c|c|c|c||}
\hline \hline Physical & Cognitive & Emotional & Social \\
\hline - high temperature & - lack of detailed informa- & - death of friends & - lack of privacy and \\
- risk of dehydration & tion about the mission & - witnessing death & space \\
- noise & - incomplete information & - inflicting death \\
- bright light & about family & - chronic danger & \\
- long-lasting darkness & - culture shock & - helplessness in the face of & \\
(e.g., during night pa- & - stimulation overload & danger & \\
trols) & - monotony accompanying & - maintaining readiness for & \\
- sleep deprivation & the performance of cer- & 24 hours a day \\
& tain duties & - longing for family & \\
\hline
\end{tabular}

Source: Developed by the authors on the basis of Figley, Nash, 2010; Lemanowicz, Szaraniec, 2003; Joseph, 2007.

The above analysis leads to the reflection that participation in combat includes nonnormative experiences, the presence of which requires significant adaptive competences. Participation in a combat mission is thus an extreme situation (Borys, 2004: 99). However, it should be noted that not all war stressors, considered as isolated stimuli, are sources of extreme stress. For example, the impact of high temperatures or noise may be considered a mere inconvenience of everyday life, if we do not take into account the context of these stimuli. However, it should be remembered that soldiers are exposed to all the stressors we have described in a chronic manner. This, combined with the inability to regenerate one's strength, causes the harmful effects 
of stress factors to accumulate and soldiers' stress becomes permanent. In addition, some stressors, such as witnessing someone's death (even once), are considered traumatic in the literature and can thus themselves be a source of extreme stress (Briere, Scott, 2010: 23).

The psychological consequences of participating in combat missions are complex, and their type and severity depend on various factors. When we think about the consequences of participating in such missions, the first association is its negative effects in the form of various types of mental health problems and with the readaptation to living in the home country. Research indicates, however, that participation in a combat mission may also result in positive consequences. Predel's research (2014: 402) showed that as many as $69 \%$ of the surveyed soldiers noticed improvements in their mental condition after returning home from the mission. Over $80 \%$ of them also declared that they had experienced improvements in their coping skills and keeping a cool head in difficult situations. Participation in combat missions - undoubtedly an extremely stressful situation - can thus lead to both negative and positive changes. Below, we look more closely at both types of consequence.

\section{NEGATIVE CONSEQUENCES OF PARTICIPATING IN A COMBAT MISSION}

The unfavorable consequences of participating in combat missions can be divided into two groups: the first includes problems of a mental nature that fulfill the criteria of specific disease entities; the second group includes difficulties associated with the repeated need to adapt to life in one's own social and family environment.

The clinical consequences (related to defined disease entities) of participation in combat missions are primarily posttraumatic stress disorder (PTSD), acute reaction to stress, addiction to alcohol or drugs, and sleep disorders. The most common disorder among veterans is posttraumatic stress disorder (Kennedy, Zillmer, 2006: 8; Simms, Watson, Doebbeling, 2002: 642; Joseph, 2007: 11), which affected about 226,000 soldiers involved in Operation Enduring Freedom and Operation Iraqi Freedom (Miles et al., 2015: 46). In the ICD-10 Classification of Mental Disorders (2009: 227), PTSD belongs to a group of neurotic disorders in somatic form, and to the subgroup described as "reaction to severe stress and adaptation disorders." We distinguish three basic groups of symptoms: (1) the presence of obsessive, vivid memories and dreams that revive painful experiences; (2) avoidance of circumstances and people associated with stressful events, and emotional blunting and isolation from others; (3) excessive vigilance and mood lability. PTSD can appear weeks or months after from suffering trauma, and is sometimes accompanied by depression, fear, and suicidal thoughts. If the symptoms last longer, the patient's condition can become chronic and may transform into a permanent personality change (Cierpiałkowska, 2012: 378). The course of PTSD and the configurations of its symptoms vary among veterans returning from combat missions and depend, among others factors, on the nature of the soldier's duties and the frequency of participation in dangerous situations (Hunt, 2010: 11), as well as to the extent to which 
events on the mission undermined the soldier's fundamental beliefs about the world (Figley, Nash, 2010: 63).

Veterans often face addiction to alcohol or drugs (Nowak, 2008: 11). Studies confirm that as many as $40 \%$ of the participants of Operation Enduring Freedom and Operation Iraqi Freedom drink in risky way (Calhoun et al., 2008; after: Klanecky, Cadigan, Martens, Rogers, 2014: 369). A factor that protects soldiers from becoming addicted after returning home from mission is having a partner (Klanecky, Cadigan, Martens, Rogers, 2014: 373).

Sleep disorders are often associated with the mental problems above mentioned, but they also constitute a separate category of disorders in the ICD-10 classification. In research conducted among psychiatrically hospitalized Polish veterans (Kosińska, Ilnicki, Petrowić, Ilnicki, Kosiński, 2014: 15-16), 87.1\% of respondents reported nightmares and $93.5 \%$ stated that they suffered from difficulties sleeping and in maintaining sleep. These studies were carried out among soldiers hospitalized after missions, so they cannot be related to the entire veterans.

In addition to experiencing the psychological consequences of participation in missions - which can be considered a specific disorder - soldiers face a wide range of readaptation problems after their return. During the mission, a soldier's functioning is based on a so-called "combat mode of operation" (Filarowska, Ilnicki et al., 2013: 142 ) - the main feature of which is to maintain vigilance 24 hours a day. After six months of this lifestyle, it becomes difficult for the soldier to abandon it and to behave as he or she did before the mission. In addition, during a soldier's absence, his or her family may develop new ways of functioning: the soldier's partner may take over his or her duties, children may become more independent. Returning to family life is therefore a difficult task, requiring much patience and effort from the veteran and the family members. The problems with this readaptation are compounded by the fact that the reality of the mission is, perhaps paradoxically, based on much simpler principles than those that prevail in a family home. The soldier on a combat mission has two main tasks to perform each day: to fulfill his or her duties and to survive. Upon returning home, these tasks are no longer so precisely determined, and suddenly soldiers again become responsible not only for themselves, but also for partners and children. They return to roles such as husband and father and to the duties that these roles impose. Soldiers are then expected to show feelings that needed to be suppressed during the mission. These considerations lead to the conclusion that veterans' return from a mission and readaptation to their former life can be very problematic, even if they does not face more serious consequences in the form of problems with mental health.

\section{POSITIVE CONSEQUENCES OF PARTICIPATION IN COMBAT MISSIONS}

The negative consequences of participation in combat missions, manifested in the form of problems with mental health and difficulties in readapting, are understandable and undisputable. Among the much less obvious consequences of such experiences are positive changes in the lives of soldiers. They occur as a result of traumatic events 
and are referred to as traumatic increases (Tedeschi, Calhoun, 2004: 3). This phenomenon has been noted among people who have experienced a range of traumatic situations, such as surviving cancer (Cordova, Giese-Davis, Golant, Kronenwetter, Chang, Spiegel, 2007: 314) and, interestingly from our perspective, participating in combat missions (Tedeschi, 2011: 140; Benetato, 2011: 415). In this case, the experience of posttraumatic growth not only causes the person to become happier, but also that his or her perception of himself or herself, of the world, and of other people changes. Such people evaluate their life and begin to appreciate more things that they did not notice before, or that seemed of little importance.

There are several areas of posttraumatic growth, including changes in self-perception, changes in relationships with other people, greater appreciation of life, and spiritual changes (Ogińska-Bulik, Juczyński, 2013: 130; Joseph, 2007: 11). In research, combat mission veterans often declare that their way of looking at the world and their system of values have changed. Soldiers often come to the conclusion that time spent with relatives is much more important than the constant struggle for wealth. Material goods become less important, while relationships with partners, children, parents, and friends are often placed at the top of life's priorities (Gumińska, 2011: 3).

Whether traumatic growth occurs at all depends on a number of factors. One of the most important factors is the intensity of the stressful experience: some researchers are of the opinion that the more intense the trauma, the more probable the occurrence of traumatic increase is; other researchers, however, claim that posttraumatic development is most probable with moderate stress intensification (Ogińska-Bulik, Juczyński, 2013: 131). Social support - whether perceived or actually received - also plays a role, increasing the chance of traumatic increase.

\section{DETERMINANTS OF THE POSITIVE AND NEGATIVE PSYCHOLOGICAL CONSEQUENCES OF PARTICIPATION IN COMBAT MISSIONS}

Participation in combat is an extreme situation that can cause both positive and negative effects for soldiers. The nature and intensity of these psychological consequences vary among the participants of a mission. Here we discuss the social and situational factors that affect whether the consequences of combat mission occur or not.

The social conditions affecting the consequences of participation in combat missions are primarily the various types of social support. Social support beneficially affects the health and well-being of an individual, giving him or her a sense of security and belonging. In addition, an extensive support network causes people to become less exposed to stressful situations, acts as a precaution (making the appearance of the stressors more difficult), or causes individuals to interpret them in different way. Social support is also associated with the so-called buffer hypothesis, meaning that in stressful situations it acts as like buffer, reducing the level of threat by helping to overcome difficulties and reduce tension (Sęk, Cieślak, 2004). A number of studies have been carried out into the relationship between social support and the intensification of mental disorders. They have shown that perceived support does not prevent the devel- 
opment of the symptoms of posttraumatic stress among victims of trauma, but support actually received from relatives during the first six months after returning from the mission serves to lower the number of disorders among soldiers. In addition, research has shown that inadequate support can lead to the development of mental disorders (Sęk, Cieślak, 2004).

The situational conditions that determine the positive and negative psychological consequences of participation in a mission - that is, the conditions related to the specificity of the combat conditions - remain largely unexplored. The following factors may have an effect on the consequences of participation in combat, though this has not yet been empirically confirmed: soldiers' relations with their commanding officer, relations with colleagues, colleagues' reactions to crisis among them, and the level of trust prevailing in the unit. These factors may cause soldiers to deal more effectively with traumatic experiences during a mission. Presumably the length of military service, the number of missions performed, the position held, the nature of the duties performed during the mission, and the intensity of combat experience can also modulate the effects of traumatic experiences.

The number of possible social and situational psychological conditions that might affect the consequences of participation in combats mission is so large, and their variety of broad, that it is impossible to consider all of them in a single study. These factors were thus selected and the research problems and study aim were formulated.

The aim of this study was to seek connections between the intensity of soldiers' combat experience during a mission, the support received from those closest to them immediately after returning home, and the psychological consequences of the mission, both positive and negative (in the form of intensification of symptoms of PTSD). It was expected that there would be a positive relationship between: (a) the intensity of combat experience and the intensity of symptoms of PTSD; (b) the intensity of combat experience and the level of posttraumatic growth; (c) the level of support received by soldiers from the people closest to them and the level of posttraumatic growth; (d) the level of support received by soldiers and the intensification of PTSD symptoms.

\section{RESEARCH SEQUENCE AND STUDY GROUP CHARACTERISTICS}

Research among members of the Polish Army is regulated by Decision No. 78 of the Minister for National Defense of 2008 [1], with amendments in 2014 [2]. According to these rules, before research begins it is necessary to obtain nonrecurring authorization to conduct the research from the Ministry of National Defense. Once we receiving this (25 February 2016), the research was carried out with the participation of the 12th Mechanized Brigade in Szczecin. All respondents were gathered in a large lecture hall. Before completing questionnaires, the soldiers were provided with information on the content of the research and how to answer the questions. The confidentiality of data, the voluntary nature of the examination, and the option of withdrawing from the research at any time were also emphasized.

Fifty-seven male soldiers took part in the study, of whom five made use of their right to withdraw and returned empty questionnaires. Then research group thus con- 
sisted of 52 soldiers who had participated in at least one combat mission. Half of them (51\%) had been on only one mission, $45 \%$ had been on two missions and $4 \%$ (two individuals) on three missions. All respondents were aged 25 to 41 years; the average age was $32.80(\mathrm{SD}=3.1)$. The vast majority (over $80 \%$ ) had secondary education, $18 \%$ of respondents had finished their education with higher education, and $2 \%$ of the respondents indicated that they had not proceeded further than vocational education. Almost 59\% described their material situation as good, $37 \%$ indicated it to be average, and $4 \%$ as poor. The majority of the respondents $(59 \%)$ lived in a city or town with more than 50,000 inhabitants, $29 \%$ in a city or town with less than 50,000 inhabitants, and the rest $(12 \%)$ lived in the countryside or a village.

\section{APPLIED RESEARCH TOOLS}

The following questionnaires were used: Combat Exposure Scale, The PTSD Checklist - Military Version, The Berlin Social Support Scales, and The Posttraumatic Growth Inventory

The Combat Exposure Scale by Terrance M. Keane et al. (1989), translated by Madej (2016), measures combat experiences. The questionnaire consists of seven questions, each concerning a different type of combat experience - for example, "How often did you open fire on an enemy?", "How often were you in danger of injury or loss of life?" The respondent answers these questions on a five-point scale, where 1 means low and 5 means high intensity of experiences. On the basis of the answers, a general score is calculated, which allows the intensity of combat experiences to be estimated.

The PTSD Checklist - Military Version, Weather et al., 2013; translated by Madej, 2016 measures the intensification of symptoms arising in response to stressful combat experiences among both soldiers on active military service and veterans. It allows the overall rate of intensification of symptoms of posttraumatic stress disorder to be calculated by calculating an arithmetic mean of scores for each symptom on scale of 1 (never) to 5 (very often). The higher the result, the greater the intensification in the symptoms. In addition, this tool also allows it to be determined whether the respondent meets the criteria for posttraumatic stress disorder from the American Psychiatric Association's DSM IV classification.

The Berlin Social Support Scales, by Schwarzer and Schultz (2000), translated by Łuszczyńska and Kowalska (2002) is a questionnaire that examines different aspects of social support. It contains six subscales, of which five were selected for the needs of the study: (1) Perceived available support (8 statements); (2) Need for support (4 statements); (3) Looking for support (5 statements); (4) Currently received support (15 statements); (5) Buffer and protection support (6 statements). The last of these is intended to be completed by both those providing and those receiving support; however, in this study it was completed only by the soldiers (as it was not possible to include the people providing support to soldiers after the mission). It is worth mentioning here that protective support refers to hiding bad news and negative emotions from someone close in order to protect them by dealing with one's own problems and feelings. Respondents scored each item on a four-point scale, where 1 means that the statement is 
completely untrue, while 4 means that the statement is completely true. The higher the score, the greater the social support.

Postraumatic Growth Inventory by Tedeschi and Colhoun (1996), in the adaptation of Ogińska-Bulik and Juczyński (2010), explores the positive effects of strongly stressful experiences. The original version of the questionnaire begins by asking the respondent to select from a list of traumatic events those which have taken place in his or her life, and to determine how much time has elapsed since it. This study omitted this part, as it was assumed that respondents would refer to the combat mission. The next step is to respond to 21 statements using a six-point scale, where 0 means "I did not experience this change as a result of the crisis" and 5 means "I experienced this change to a very large extent." This tool allows four types of positive consequence of stressful experience to be assessed: (1) changes in the perception of oneself (perception of new possibilities, greater sense of personal strength); (2) changes in relations with others (greater sense of bond with others, increase in empathy); (3) greater appreciation of life (change in priorities, greater appreciation of life every day, change in life philosophy); (4) spiritual changes (increase in religiousness). The arithmetic mean of the answers to all questions determined the overall traumatic growth rate.

\section{RESULTS}

The basic aim of this research was to try to determine the factors that determine the psychological consequences of participation in combat missions. At this point, it is worth briefly discussing the descriptive statistics that characterize the dependent variable. The mean of the results $(\mathrm{M}=1.61, \mathrm{SD}=0.77$, minimum score $=1$, maximum obtained score -3.24 ) indicates that the soldiers rarely experienced psychological disturbances related to their participation in combat missions. Five respondents $(9.6 \%)$ can be diagnosed with a clinical form of posttraumatic stress disorder. In addition, almost half of respondents (48\%) replied affirmatively to the question asking whether anyone in their environment had noticed that they had changed after their return from the mission. The descriptive statistics of the results of the instruments testing for positive psychological changes following combat missions suggest that such changes did occur among the respondents, but that their intensity varies: positive self-perception was most altered and spirituality least altered as a result of participating in combat missions (Table 2).

Table 2

Postraumatic Growth Inventory - the descriptive statistics ( $\mathbf{N}=\mathbf{5 2})$

\begin{tabular}{||l|c|c||}
\hline \multicolumn{1}{|c|}{ Scale } & M & SD \\
\hline Changes in the perception of oneself & 3.34 & 1.08 \\
\hline Changes in relations with others & 2.85 & 1.10 \\
\hline Appreciation of life & 3.25 & 1.30 \\
\hline Spiritual changes & 1.88 & 1.38 \\
\hline
\end{tabular}


Correlation analysis was used to check whether the intensification of combat stress was related to both positive and negative psychological changes. However, this failed to demonstrate any significant correlation between the intensity of combat experience during missions and the intensity of symptoms of posttraumatic stress disorder $(\mathrm{r}=$ $-0.051 ; p=0.72)$. Moreover the intensification of combat stress was not related to either the overall level of traumatic growth $(\mathrm{r}=-0.11 ; \mathrm{p}=0.53)$ or to its individual aspects, which include changes in self-perception $(r=-0.14 ; \mathrm{p}=0.49)$; changes in relationships with other people $(r=-0.03 ; p=0.63)$; increased appreciation of life $(r=$ $-0.16 ; \mathrm{p}=0.50)$, and spiritual changes $(\mathrm{r}=-0.04 ; \mathrm{p}=0.63)$.

The next research question concerned the relation between social support and the positive and negative psychological consequences of participation in combat missions. The following tables present the results of correlation analysis between the aspects of social support studied here and posttraumatic growth.

Table 3

Correlations between Social Support Scales and Posttraumatic Growth Scales

\begin{tabular}{|l|c|c|l|c|c|c||}
\hline & $\begin{array}{c}\text { Social } \\
\text { Support, } \\
\text { total score }\end{array}$ & $\begin{array}{c}\text { Available } \\
\text { support }\end{array}$ & $\begin{array}{c}\text { Need for } \\
\text { support }\end{array}$ & $\begin{array}{c}\text { Looking } \\
\text { for } \\
\text { support }\end{array}$ & $\begin{array}{c}\text { Received } \\
\text { support }\end{array}$ & $\begin{array}{c}\text { Buffer and } \\
\text { protection } \\
\text { support }\end{array}$ \\
\hline PG, total score & 0.17 & 0.02 & $0.33^{* *}$ & $0.25^{*}$ & 0.07 & $0.28^{* *}$ \\
\hline PG, Self perception & 0.19 & -0.02 & $0.30^{* *}$ & 0.21 & 0.10 & $0.31^{* *}$ \\
\hline PG, relations with other & 0.19 & 0.06 & $0.45^{* * *}$ & $0.33^{* *}$ & 0.03 & $0.23^{*}$ \\
\hline PG, Appreciation of life & 0.05 & -0.01 & 0.11 & 0.03 & 0.08 & 0.19 \\
\hline PG,Spiritual changes & 0.08 & 0.01 & 0.18 & $0.26^{*}$ & 0.01 & -0.02 \\
\hline
\end{tabular}

$\mathrm{PG}=$ Posttraumatic Growth; $* \mathrm{p}<0,1 ; * * \mathrm{p}<0,05 ; * * * \mathrm{p}<0,01$.

The results confirm the connection between social support and the positive psychological effects of the mission - i.e., posttraumatic growth. The results also demonstrate that there is a correlation between the general level of posttraumatic growth and the three aspects of social support: the need for support, the search for support, and buffer and protective support. These variables are positively correlated, so the more support a soldier needs, the more he or she seeks it, and the more buffer support he or she shows to those close to him, the higher the level of posttraumatic growth. The statistical analysis also showed correlations between some aspects of social support and some subcategories of positive mental changes that create posttraumatic growth. There is a statistically significant relation between changes in self-perception and the need for support, and between changes in self-perception and buffer and protective support. Changes in relationships with other people are strongly related to the need for support, slightly more weakly related to seeking support and even more weakly, though still significantly ( $\mathrm{p}<0.1$ ), to buffer and protection support. There was also a marginally significant correlation $(\mathrm{p}<0.1)$ between spiritual changes and seeking support $(\mathrm{r}=0.260$; significance $=0.063)$. All these correlations were positive.

Contrary to expectations, the statistical analysis showed that the intensification of PTSD symptoms correlates with only one aspect of social support - namely buffer and protection support $(r=0.344 ; p=0.012)$. This correlation is positive, so the higher the 
level of buffer and protective support, the lower the intensification of symptoms of PTSD. Statistically significant direct correlations between the general level of social support and its aspects other than buffering and protective support and the intensification of symptoms of PTSD were not demonstrated.

\section{DISCUSSION}

The main aim of this research was to determine the relationships between the intensity of combat experiences, social support, and the psychological consequences of combat missions - both positive (in the form of posttraumatic growth) and negative consequences (the intensification of symptoms of PTSD). Analysis of the results was helpful in achieving this aim.

The most surprising result is the lack of direct correlation between the intensity of combat experience and the intensity of negative psychological effects of the mission in the form of PTSD symptoms. The research results suggest that the nature of soldiers' experiences on a mission is not directly related to the symptoms of posttraumatic stress syndrome experienced. It seems that for the negative consequences of participation in combat missions, the presence of traumatic events is less important than the subjective means of interpreting or dealing with them. Nevertheless it cannot be excluded that this result does not reflect the true psychological condition of the respondents. The circumstances of the study, such the fact that soldiers were ordered by their superiors to participate in the study, the presence in the hall during the study of not only the researcher, but also of a high-ranking military psychologist, and the location of the study (a military base) could have affected the answers given. Soldiers may not have felt sufficiently confident to answer all questions frankly: some questions, especially those related to the occurrence of psychological disturbances, may have been answered conservatively.

Interestingly, the intensification in the symptoms of posttraumatic stress disorder was related only to buffer and protective support - that is, the number of psychological disturbances went hand in hand with the tendency of soldiers to engage in behaviors such as not informing those close to them about their bad moods or aversion to sharing painful memories from the mission. Such behavior is aimed at protecting of those close to them from worrying excessively about the soldier and burdening them with their own problems. From the point of view of psychological well-being, this behavior proves unfavorable: the accumulated negative emotions remain unexpressed and are suppressed, resulting in the inability to work them out. It should be noted that avoiding the expression of emotions is one of the main risk factors for the development of posttraumatic stress disorder (James, Gilliand, 2010: 139). Avoiding talking about troublesome memories thus makes it impossible to deal with traumatic experience. Our research has shown that the more soldiers protect those close to them by not describes their experiences on missions, the more they face symptoms such as anxiety, vivid memories, and persistent avoidance of the stimuli associated with painful experiences.

Apart from seeking the determinants of psychological disturbances, this research has also aimed to determine factors that are important for the level of posttraumatic 
growth. It is worth emphasizing that posttraumatic growth - like the intensification of PTSD symptoms - is not directly related to the intensity of combat experiences, and that the importance of other factors has been shown here: these are primarily aspects of social support, such as the need for support and seeking support. Our results thus suggest that it is not so much the occurrence of traumatic events as the personal resources that allow soldiers to seek support that assist in the development of positive psychological changes as a result of participation in combat missions. These types of support are particularly strongly related to aspects of positive psychological consequences such as changes in relations with other people and changes in self-perception. It seems from our results that the need for support is reflected in both the reevaluation of the importance of relations with others and in increases in the sense of personal strength. Soldiers who indicated a greater need of help from others in crisis situations also stated more often that, after the mission, they began to better appreciate the presence of those close to them and to realize how important these close people were to them. It is interesting that the study did not show any connection between any category of positive changes after the mission and the support actually received by the soldier; the results suggest that the mere availability of support and the possibility of taking advantage of it are more important than the actual provision of support to soldiers. It can be assumed that soldiers who actively seek support and declare that they need to obtain it are also more open and more willing to share their difficult experiences, which helps to release negative tension and counteract the negative effects of suppressing emotions. The connection between buffer and protective support and positive changes in both relations with other people and self-perception is interesting. It should be remembered that not sharing with family members those difficulties arising from participation in combat was significantly associated with the intensification of symptoms of posttraumatic stress disorder. This style of functioning thus seems have both its advantages and disadvantages. On one hand, protecting those close to the soldier from painful experiences is the basis of appreciating family relations and a source of personal strength; on the other hand, it leaves the soldier with emotions that are not worked out and thus express themselves in symptoms of posttraumatic stress. The research also allowed observation of the correlation between the search for support and positive changes in the spiritual sphere. People seeking support often find it in a higher power or religious community, which can lead to the development of spirituality or faith. The study did not reveal any correlations between the category of growth changes, such as greater appreciation of life, and any of factors studied. The results suggests that experiences such as the enjoyment of everyday life and the desire to use abilities awakened as a consequence of participation in combat missions are independent of social support. It may thus be that increased affirmation of life is the result of personal predispositions that allow the soldier to make the fact of having survived combat into a resource that can change his or her attitude to reality.

We should add that the statistical analysis of the results was based on a correlation model, and it is thus impossible to draw clear conclusions concerning the direction of the relations between the variables. The correlation detected between the need for support and changes in relations with others therefore does not necessarily mean that the need for support determines positive changes in relations with others. We thus 
cannot exclude the possibility that the experience of posttraumatic growth in the form of positive changes in relations with others contributed to the increase in the need for support.

\section{CONCLUSIONS AND PRACTICAL IMPLICATIONS OF THE RESEARCH}

The results of carried this study allow us to present several important conclusions. Firstly, the psychological consequences of participation in combat missions seem to be relatively independent of the intensity of combat experiences. Although the research context, as discussed earlier, could have contributed a small number of symptoms being revealed, and thereby may fail to reflect the real experiences of the respondents, we cannot nonetheless exclude the possibility that the psychological consequences of participation in the mission are more dependent on personality variables than on the presence of specific situations. Future studies should take a closer look at the relationships between the psychological consequences of participation in missions and aspects of personality, such as dealing with stress, cognitive abilities, and temperament. It also cannot be excluded that aspects of the situation such as the quality of interpersonal relations on the mission or the length of service of a soldier can contribute to the way of dealing with the difficult situation of participating in combat.

The next conclusion concerns ours results indicating that soldiers are very reluctant to talk to those close to them about what happens during missions. They do not want to burden those close to them with their memories or worry them with bad moods or concerns about their health. This strategy alone was associated with the intensification of psychological disorders. In the context of this information, it seems important to create formal support networks to assist soldiers returning from missions - to enable them to obtain support from someone who is not emotionally involved in the situation. In this way, the possibility of working through negative emotions outside the family will be created.

Our results may be useful for those dealing professionally with the psychological preparation of soldiers departing on a mission, as well as for specialists who provide psychological support to soldiers and their families during and after missions. The results recommend the creation of formal support networks at each stage of the soldier's participation in the mission - during preparations at home, during the mission, and after returning home (cf. Lapierre, Schwegler, LaBauve, 2007: 941). They also suggest that having a place nearby where soldiers can go for assistance is helpful: it is possible that many of them will never make use of this facility, but the feeling that there is someone outside their family who is willing to listen and to support them seems to be important and helpful.

This study has certain methodological imperfections. The first is that the sample size was only 52 , which results from the difficulty of reaching soldiers who have participated in at least one combat mission in Iraq or Afghanistan. In future, it would be worthwhile to carry out similar research on a larger sample of respondents, in order to confirm our results and conclusions. Another shortcoming is that we took into account 
only the subjective statements of soldiers concerning, for example, their behavior after the mission. The situation may look different from the viewpoint of those close to the soldiers. Finally, it should be emphasized that the research covered only soldiers who are still in the army, meaning that after their return from the mission, their physical and mental state of health was assessed by specialists as being sufficiently good to allow continuation of active service. Those who had to leave the army due to serious health problems were thus not taken into consideration in the research. This means that our conclusions concern a specific group of soldiers: those who have generally dealt well with themselves and with reality.

\section{REFERENCES}

Baranowska A. (2008), Techniki adaptacji do życia w instytucji totalnej. Na przykładzie żolnierzy - mieszkańców obozu Babilon w Iraku, Torun.

Benetato B. (2011), Posttraumatic Growth Among Operation Enduring Freedom and Operation Iraqi Freedom Amputees, „Journal of Nursing Scholarship”, Vol. 43.

Borys B. (2004), Sytuacje ekstremalne i ich wptyw na stan psychiczny człowieka, „Psychiatria”, Vol. 1, No. 2.

Briere J., Scott C. (2010), Podstawy terapii traumy. Diagnoza i metody terapeutyczne, Warszawa.

Cendrowski J., Swebocki S. (1973), Psychologia walki i dowodzenia, Warszawa.

Cierpiałkowska L. (2012), Psychopatologia, Warszawa.

Cordova M., Giese-Davis J., Golant M., Kronenwetter C., Chang V., Spiegel D. (2007), Breast Cancer as Trauma: Posttraumatic Stress and Posttraumatic Growth, „Journal of Clinical Psychology in Medical Settings", Vol. 14.

Figley C., Nash W. (2010), Stres bojowy. Teoria, badania, profilaktyka i terapia, Warszawa.

Filarowska M., Ilnicki S., Młożniak E., Laskowska A., Tworus R. (2013), Problemy adaptacyjne żon polskich weteranów poszkodowanych w misjach w Iraku i Afganistanie, ,Lekarz Wojskowy”, Vol. 2.

Gumińska A. (2011), Stres w czasie stużby poza granicami państwa (materiał do zajęć psychoedukacyjnych z żotnierzami), Ministerstwo Obrony Narodowej, Departament Wychowania i Promocji Obronności, Warszawa.

Hunt N. (2010). Memory, war, trauma, Cambridge.

James R. K., Gilliland B. E. (2010), Strategie interwencji kryzysowej, Warszawa.

Joseph C. (2017), An overview of psychological factors and interventions in air combat operations, „International Journal of Agile Systems and Management”, Vol. 51 (2).

Kennedy C., Zillmer E. (2006), Military Psychology, Nowy Jork.

Klanecky A., Cadigan J., Martens M., Rogers R. (2014), Examining spouse/partner presence as a moderator in the relationship between mental health symptoms and alcohol use in OEF/ OIF veterans, „Military Psychology”, Vol. 26.

Kosińska L., Ilnicki S., Petrivić A., Ilnicki P., Kosiński K. (2014), Zaburzenia snu u weteranów Polskich Kontyngentów Wojskowych, „Lekarz Wojskowy”, Vol. 1.

Lapierre C., Schwegler A., LaBauve B. (2007), Posttraumatic stress and depression symptoms in soldiers returning from combat operations in Iraq and Afghanistan, „Journal of Traumatic Stress", Vol. 20 (6). 
Lemanowicz P., Daroszewska T. (2004), Vademecum stresu I pomocy psychologicznej w misjach wojskowych, Ministerstwo Obrony Narodowej, Departament Wychowania i Promocji Obronności, Warszawa.

Międzynarodowa Klasyfikacja Chorób i Problemów Zdrowotnych ICD-10 (2009), Rewizja dziesiąta, Vol. I, Światowa Organizacja Zdrowia.

Miles S., Graham D., Teng E. (2015), Examining the influence of mild traumatic brain injury and posttraumatic stress disorder on alcohol use disorder in OEF/OIF Veterans, „Military Medicine", Vol. 180.

Nowak B. (2008), Stres bojowy. Przyczyny, oznaki, zapobieganie (materiaty do zajęć z ksztatcenia obywatelskiego), Ministerstwo Obrony Narodowej, Departament Wychowania i Promocji Obronności, Warszawa.

Ogińska-Bulik N., Juczyński Z. (2013), Rozwój potraumatyczny - charakterystyka i pomiar, „Psychiatria", Vol. 7, No. 4.

Ogley M. A., Bradley D., Santiago P., Reynolds M. D. (2012), Description of combat and operational stress control in Regional Command East, Afghanistan, „Military Medicine”, Vol. 177 (11).

Predel G. (2014), Psychologiczne konsekwencje udziału w operacji wojskowej w Afganistanie, „Lekarz Wojskowy", Vol. 4.

Simms L., Watson D., Doebbeling B. (2002), Confirmatory factor analyses of posttraumatic stress symptoms in deployed and nondeployed veterans of the Gulf War, „Journal of Abnormal Psychology", Vol. 111 (4).

Sęk H., Cieślak R. (2004), Wsparcie społeczne, stres i zdrowie, Warszawa.

Tedeschi R. G. (2011), Postraumatic Growth in Combat Veterans, "Journal of Clinical Psychology in Medical Settings", Vol. 18.

Tedeschi R. G., Calhoun L. G. (2004), Posttraumatic growth: conceptual foundations and empirical evidence, "Psychological Inquiry", Vol. 15.

Watkins K., (2014), Deployment stressors: A review of the literature and implications for member of the Canadian Armed Forces, „Res Militaris”, Vol. 4 (2).

Weathers F. W., Litz B. T., Keane T. M., Palmieri P. A., Marx B. P., Schnurr P. P. (2013), The PTSD Checklist for DSM-5 (PCL-5)m, www.ptsd.va.gov.

Decyzja Nr 78/MON Ministra Obrony Narodowej w sprawie prowadzenia badań spolecznych w resorcie obrony narodowej (2008).

Decision No. 78/MON of Minister of National Defense of 15 February 2008 concerning social research in the department of national defense.

Decision No, 68/MON of Minister of National Defense of 6 March 2008 amending the decision concerning research in the department of national defense.

\begin{abstract}
The participation of soldiers in combat missions is one of the tasks that requires not only physical - but because of stressors - also psychological preparation. Participation in warfare involves exposure to physical, cognitive, emotional and social inconvenience and is considered an important risk factor for the psychological disturbances. However, the literature on the subject also indicates the positive effects of confrontation with the stressors (e.g. postraumatic growth). The aim of the study was to determine whether the intensity of combat exposure and social support are related to both the negative and the positive psychological consequences of participating in warfare. The study, conducted by soldiers participating in the Afghan war, showed no connec-
\end{abstract}


tion between the intensity of combat experience and the well-being of soldiers. Not informing the family about difficulties experienced by soldiers was related to a greater number of psychological disturbances. Moreover, it turned out that not received social support, but the soldier's conviction about the possibility of receiving this form of help, together with refraining from sharing their difficulties with family members, contributed to positive psychological changes. The results demonstrated that the psychological effect of participating in a military mission is not so much dependent on the intensity of the combat experience, as from the soldier's conviction that social support is available from non-family member.

Keywords: military stress, PTSD, social support, postraumatic growth

\section{SYTUACYJNE I SPOLECZNE UWARUNKOWANIA PSYCHOLOGICZNYCH KONSEKWENCJI UDZIALU W MISJI BOJOWEJ - WYNIKI BADAŃ}

\section{STRESZCZENIE}

Udział żołnierzy w misji bojowej jest jednym z zadań, które wymaga nie tylko przygotowania fizycznego, ale - z racji obciążenia stresorami - także psychologicznego. Uczestnictwo w działaniach wojennych wiąże się z ekspozycją na obciążające bodźce fizyczne, poznawcze, emocjonalne oraz społeczne i jest uznawane za istotny czynnik ryzyka dla zakłóceń psychologicznych. Jednak w literaturze przedmiotu wskazuje się także pozytywne skutki konfrontacji z obciążającymi sytuacjami, do których odnosi się pojęcie wzrostu potraumatycznego. Przeprowadzone badanie zmierzało do odpowiedzi na pytanie, czy intensywność doświadczeń bojowych oraz wsparcie społeczne pozostają w związku zarówno z negatywnymi, jak i pozytywnymi psychologicznymi konsekwencjami udziału w misji bojowej. Przeprowadzone badanie, w którym wzięli udział żołnierze uczestniczący w wojnie na terenie Afganistanu, wykazało brak związku między intensywnością doświadczeń bojowych a samopoczuciem żołnierzy. Nieinformowanie rodziny o swoich trudnościach szło w parze z większą liczbą zakłóceń psychologicznych. Jednocześnie okazało się, że nie tyle faktycznie otrzymywane wsparcie, co przekonanie żołnierza o sensowności i możliwości otrzymania tej formy pomocy, wraz z powstrzymywaniem się od dzielenia swoimi trudnościami z członkami rodziny, przyczyniało się do pozytywnych zmian psychologicznych. Uzyskane wyniki skłaniają do wniosku, że psychologiczne skutki udziału w misji wojskowej są nie tyle zależne od intensywności doświadczeń bojowych, co od przekonania żołnierza, iż może on uzyskać pomoc od osoby bliskiej spoza rodziny.

Słowa kluczowe: stres bojowy, PTSD, wsparcie społeczne, wzrost potraumatyczny 